\title{
Development of the Scale to Measure the Attitude of Farmers towards Farmer Producer Organizations (FPOs)
}

\author{
Shivani Dechamma*, B. Krishnamurthy, M. T. Lakshminarayan and M. Shivamurthy
}

Department of Agricultural Extension, University of Agricultural Sciences, GKVK, Bengaluru, Karnataka, India

*Corresponding author

\begin{abstract}
A B S T R A C T
Keywords

Relevancy,

Reliability,

Validity, Attitude,

Farmer producer

organizations

Article Info

Accepted:

24 October 2020

Available Online:

10 November 2020

Farmer Producer Organizations (FPOs) are being established so that it can help farmers in earning more returns through collective input purchase, collective marketing, processing, increasing productivity through procuring better inputs, augmenting knowledge of farmers in better management practices and ensuring quality. An attempt was made to develop a standardized scale to analyze the attitude of members towards Farmer Producer Organization (FPO) using summated rating methods suggested by Likert and Edwards. The attitude scale developed was found to be highly reliable and valid. The final attitude scale consisted of 22 statements and this scale was administered to 30 farmers in Doddabalapura district in Karnataka during 2019-2020 to analyse their attitude of members towards Farmer Producer Organization (FPO). These farmers were personally interviewed using schedule. The results revealed that a vast majority of farmers $(73.33 \%)$ had favourable to more favourable attitude towards Farmer Producer Organization (FPO). The possible reason is that large number of members of FPO is small and marginal farmers in the project area. They felt the necessity of associations are more essential for their sustained development than large farmers, hence the results.
\end{abstract}

\section{Introduction}

Farmer Producer Organizations (FPOs) are being established so that it can help farmers in earning more returns through collective input purchase, collective marketing, processing, increasing productivity through procuring better inputs, augmenting knowledge of farmers in better management practices and ensuring quality. Member based FPOs offer a proven pathway to successfully deal with a range of challenges that confront farmers today, especially small producers. Overcoming the constraints imposed by the small size of their individual farms, FPO members are able to leverage collective strength and bargaining power to access financial and non- financial inputs, services and appropriate technologies, reduce transaction costs, tap high value markets and enter into partnership with private entities on more equitable terms. With fragmentation of the holdings due to generational transfer unlikely to abate, FPOs offer a form of 
aggregation irrespective of land titles with individual producers and uses the strength of collective planning for production, procurement and marketing to add value to member's produce. International and national experience in the performance of FPOs makes a strong case for policy support to memberbased farmer bodies, to significantly increase their power in the market place, reduce risks and help them move up in the agri value chain.

Farmers Organization are essential institutions for the empowerment, poverty alleviation and advancement of farmers and also the rural poor. Politically, Farmers Organization strengthens the political power of farmers, by increasing the likelihood that their necessity and opinions are heard by policy makers and the public. Economically, Farmers Organizations can help to farmers gain skills, access inputs, form enterprises, process and market their products more effectively to generate higher incomes. By organizing, farmers can access information needed to. Produce, add value, market their commodities and develop effective linkages with input agencies such as financial service providers, as well as output markets. Farmers Organizations can achieve economies of scale, thereby lowering the costs and facilitating the processing and marketing of agricultural commodities for individual farmers. Marketing-oriented Farmer Organizations can assist their members to purchase necessary inputs and equipment, meet quality standards and manage the drying, storage, grading, cleaning, processing, packing, and branding, collection and transportation of produce. In this way Farmer Organizations provide a more reliable supply to buyers and sell larger quantities at higher prices. Organized farmers have greater bargaining power than individuals and are better able to negotiate with other more powerful market players to ultimately increase the profits that accrue to farmers rather than intermediaries and buyers. Collectivization of farmer producers, especially small and marginal farmers, into producer organizations has emerged as one of the most effective pathways to address the many challenges of agriculture. Most importantly, role of FPO in improved access to investments, technology, inputs and markets. It is found to be one of the most appropriate institutional forms for bringing about mobilization and capacity building of farmers in order to leverage their production and marketing strength. The agricultural marketing continues to be the main stay of life for majority of the Indian population, as more than 58 per cent of the population depends on agriculture.

\section{Materials and Methods}

The study was carried out in Doddaballapura district of the Karnataka State. One nonsample farmer producer organization was selected for the study. Thus, study was conducted on non-sample farmer producer organization. This pilot study was carried out in Doddaballapura district with the 30 members of the Rajaghatta Horticulture Farmer Producer Company Ltd in a systematic way and by organizing Focused Group Discussion (FGD) to discuss all the relevant aspects of farmer producer organization. During this study, following tasks have been completed:

Item analysis of the selected items for 'Attitude scale'.

Reliability test of statements of 'Attitude scale' was carried out.

Thirty members of the Farmer Producer Organization (FPO) were personally interviewed using the scale developed to measure their attitude towards the organization. 
The collected data was scored and analysed using frequency and percentage.

\section{Results and Discussion}

Development of scale to measure the attitude of farmers towards Farmer Producer Organization

Attitude is the degree of positive or negative affect associated with some psychological object, person, ideas, institution or a phenomenon (Thurstone, 1946). Attitude was operationally defined as the degree of positive or negative feelings or affect of members towards Farmer Producer Organization.The method suggested by Likert (1932) and Edwards (1969) in developing summated rating scale was followed in the construction of the scale to measure the attitude of farmers towards Farmer Producer Organizations.

\section{Procedure followed for development of scale}

Collection of items/ statements: The items have been carefully edited and selected in accordance with set criteria as the items in any psychological test. The first step in the construction of attitude scale was to collect exhaustive statements/ items pertaining to the FPOs each expressing some opinion about the psychological object under the study. A large number of items were collected from literature, informal discussions with agriculture extension experts, the other experts from the selected areas and informal interviews with the members of FPOs and director and members of the center of Excellence for FPOs. Tentative list of 82 statements pertaining to the attitude of members towards the FPOs was prepared.

Editing of the items: The statements were carefully edited, revised and restructured based on the 14 criteria enunciated by
Edwards (1969) and Thurstone and Chave (1929).As a consequence, 27 statements were eliminated. The remaining 55 attitude statements were included for further analysis.

Relevancy analysis: The selected items were then subjected to scrutiny by an expert panel of judges to determine their relevancy and subsequent screening of items for their inclusion in the final scale.In this context, 55 statements were mailed to 110 experts in the field of social sciences working in State Agricultural Universities, Indian Council of Agricultural Research Institutes and MANAGE, to critically evaluate the relevancy of each statement viz. Most Relevant (MR), Relevant (R), Somewhat Relevant (SWR), Less Relevant (LR) and Not Relevant (NR) with the score of 5,4,3,2 and 1, respectively. The judges were also requested to make necessary modifications and additions or deletion of statements, if they desired to. A total of $80(72.73 \%)$ judges returned the questionnaires duly completed and these were considered for further processing. From the data gathered, 'relevancy percentage' and mean relevancy score' were worked out for all the 55 statements. Using these criteria, individual statements were screened for relevancies using the following formulae:

$$
\begin{gathered}
\text { R.P. }=\frac{\mathrm{MR} \times 5+\mathrm{R} \times 4+\mathrm{SWR} \times 3+\mathrm{LR} \times 2+\mathrm{NR} \times 1 \times 100}{\text { Maximum possible score }} \\
\text { M.R.S. }=\frac{\mathrm{MR} \times 5+\mathrm{R} \times 4+\mathrm{SWR} \times 3+\mathrm{LR} \times 2+\mathrm{NR} \times 1}{\text { No. of judges responded }}
\end{gathered}
$$

Accordingly, statements having 'relevancy percentage' of 75 per cent and above and mean relevancy score of 3.75 and above were considered for final selection. 32 attitude statements were retained after relevancy test and these statements were suitably modified and written as per the comments of the judges wherever applicable. 
Item analysis: To delineate the items based on the extent to which they can differentiate the attitude items about FPOs as favourable or unfavourable. Item analysis was carried out on the items selected in the first stage. 32 statements were subjected for ' $t$ test' to know the difference in highest and lowest responses for the relevancy. Based upon the total scores, the judges were arranged in descending order. The top 25 per cent of the respondents with their total scores were considered as high group and the bottom 25 per cent as the low group so that these two groups provided the criterion groups in terms of evaluating the individual statements.Thus, out of 30 members of Rajaghatta Horticulture Farmer Producer company Ltd to whom the items were administered for item analysis, eight members with highest and eight members with lowest scores were used as criterion groups to evaluate individual items. The critical ratio, that is, the ' $t$ ' value which analyses the extent to which a given statement differentiates between the better and poor groups of respondents for each statement, was calculated by using the following formula:

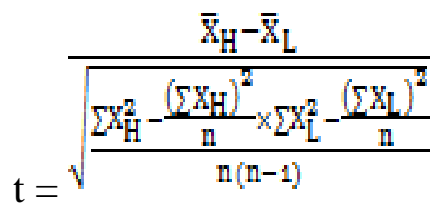

Where,

$\bar{X}_{H}=$ The mean score on given statement of the high group

$\overline{\mathrm{X}}_{\mathrm{L}}=$ The mean score on given statement of the low group

$\sum \mathrm{X}_{\mathrm{H}}^{2}=$ Sum of squares of the individual score on a given statement for high group

$\sum X_{L}^{2}=$ Sum of squares of the individual score on a given statement for low group $\mathrm{n}=$ Number of respondents in each group

$\sum=$ Summation

$\mathrm{t}=$ The extent to which a given statement differentiates between the high and low groups.

After computing the ' $\mathrm{t}$ ' value for all the 32 statements, 22 attitude statements with ' $t$ ' value equal to or greater than 1.645 were finally selected and included in the final attitude scale. Ten statements were nonsignificant.14 statements were significant at one per cent level and the remaining 6 statements were significant at five per cent level. Out of the remaining 22 statements, it contains 10 negative statements and 12 positive statements.

\section{Standardization of scale}

The reliability and validity were ascertained for the standardization of the scale.

\section{Reliability of the scale developed}

The split-half method was employed to test the reliability of the attitude scale. The value of correlation coefficient was 0.5716 and this was further corrected by using Spearman Brown formula to obtain the reliability coefficient of the whole set. The ' $r$ ' value of the scale was 0.7274 , which was significant at one per cent level indicating the high reliability of the scale. It was concluded that the attitude scale constructed was reliable.

\section{Half test reliability formula}

$$
\mathbf{r}_{1 / 2}=\frac{\mathrm{N}\left(\sum X Y-\left(\sum X\right)\left(\sum Y\right)\right.}{\sqrt{\left(N \sum X^{2}-\left(\sum X\right)^{2}\right)\left(N \sum Y^{2}-\left(\sum Y\right)^{2}\right.}}
$$

Where,

$\sum \mathrm{X}=$ sum of the socres of the odd number items 
$\sum \mathrm{Y}=$ sum of the scores of the even numbers items

$\sum X^{2}=$ sum of the squares of the odd number items

$\sum Y^{2}=$ sum of the squares of the even number items

Test reliability formula

$$
\mathrm{r}_{11}=\frac{\mathrm{r}_{1 / 2}}{1+\mathrm{r}_{1 / 2}}
$$

Where,

$r_{1 / 2}=$ Half test reliability

Validity of the scale: The data was subjected to statistical validity, which was found to be 0.8528 for scale which is greater than the standard requirement of 0.70 . Hence, the validity coefficient was also found to be appropriate and suitable for the tool developed. Thus, the developed scale to measure the attitude of members towards FPOs was found feasible and appropriate.

\section{Validity of the scale}

Validity formula

$\mathrm{V}=\sqrt{\mathrm{r}}$

\section{Administration of the scale}

The final scale consists of 22 statements for determining the attitude of members towards FPOs. The response was collected on a fivepoint continuum, namely, Strongly Agree (SA), Agree (A), Undecided (UD), Disagree (DA), and Strongly Disagree (SDA) with assigned score of 5, 4, 3, 2 and 1 respectively for positive statements and reverse scoring for negative statements.

Table.1 Scale to measure the attitude of members towards the Farmer Producer Organization (FPO)

\begin{tabular}{|c|c|c|c|c|}
\hline Sl. No. & Attitude statements & $\mathbf{R P}$ & MRS & t-value \\
\hline 1. & FPOs help in increasing confidence among farmers & 93.75 & 4.69 & $2.21 * *$ \\
\hline 2. & $\begin{array}{l}\text { FPOs provide needful information on improved } \\
\text { agricultural practices }\end{array}$ & 89.25 & 4.46 & $2.19 * *$ \\
\hline 3. & $\begin{array}{l}\text { FPOs is not a long- term solution to the problems of } \\
\text { price inflation }\end{array}$ & 86.00 & 4.30 & $2.11 * *$ \\
\hline 4. & FPOs is a boon for farmers & 86.25 & 4.31 & $2.13 * *$ \\
\hline 5. & FPOs mismanages the local resources & & & \\
\hline 6. & Much is talked about FPOs but little work is done & 77.50 & 3.88 & $1.78^{*}$ \\
\hline 7. & Organizing farmers into groups is waste of money & 83.50 & 4.18 & $2.03 * *$ \\
\hline 8. & $\begin{array}{l}\text { FPOs have created more problems for members than } \\
\text { solving }\end{array}$ & 81.25 & 4.06 & $2.00 * *$ \\
\hline 9. & $\begin{array}{l}\text { Attending FPOs work is time consuming for the } \\
\text { members }\end{array}$ & 83.25 & 4.16 & $2.02 * *$ \\
\hline 10. & Activities of FPOs are not as per members needs & 80.00 & 4.00 & $1.90 *$ \\
\hline 11. & $\begin{array}{l}\text { I feel that FPOs is a prospective system to empower } \\
\text { farmers }\end{array}$ & 78.00 & 3.90 & $1.80^{*}$ \\
\hline 12. & FPOs are not potential enough to bring about agricultural & 87.25 & 4.36 & \\
\hline
\end{tabular}




\begin{tabular}{|c|c|c|c|c|}
\hline & development & & & $2.14 * *$ \\
\hline 13. & $\begin{array}{l}\text { I endorse that FPOs is farmers friendly approach to sale } \\
\text { farm products }\end{array}$ & 84.75 & 4.24 & $2.07 * *$ \\
\hline 14. & FPOs induces cosmopolitness of its members & 85.75 & 4.29 & $2.11 * *$ \\
\hline 15. & $\begin{array}{l}\text { FPOs inculcate the decision-making ability among their } \\
\text { members }\end{array}$ & 84.75 & 4.24 & $2.07 * *$ \\
\hline 16. & FPOs work on the principle of democracy & 82.50 & 4.13 & $2.01 * *$ \\
\hline 17. & $\begin{array}{l}\text { FPOs provide need-based consultancy services to the } \\
\text { members }\end{array}$ & 84.25 & 4.21 & $2.06 * *$ \\
\hline 18. & FPOs is not rigid as co-operatives & 77.75 & 3.89 & $1.79 *$ \\
\hline 19. & $\begin{array}{l}\text { Administration / management of FPOs involve too much } \\
\text { of autocracy }\end{array}$ & 85.25 & 4.26 & $2.09 * *$ \\
\hline 20. & FPOs increase overhead charges & 74.50 & 3.73 & $1.76^{*}$ \\
\hline 21. & $\begin{array}{l}\text { Benefits from government / other institutions could be } \\
\text { availed by FPOs members }\end{array}$ & 84.50 & 4.23 & $2.08 * *$ \\
\hline 22. & $\begin{array}{l}\text { Peer pressure affects the functioning of Farmers } \\
\text { Producer Organization }\end{array}$ & 78.00 & 3.90 & $1.81 *$ \\
\hline
\end{tabular}

Table.2 Overall attitude of the members towards Farmers Producer Organization (FPO)

\begin{tabular}{|c|l|c|c|c|c|}
\hline Sl. No & Categories & Criteria & Score & \multicolumn{2}{|c|}{ Attitude of farmers } \\
\hline $\mathbf{1}$ & Less Favourable & $\begin{array}{c}\text { Less than } \\
\text { (Mean- } 1 / 2 \text { SD) }\end{array}$ & $<73.426$ & 8 & 26.67 \\
\hline $\mathbf{2}$ & Favourable & $\begin{array}{c}\text { Between } \\
(\text { Mean } \pm 1 / 2 \text { SD) }\end{array}$ & $73.426-77.441$ & 12 & 40.00 \\
\hline $\mathbf{3}$ & More Favourable & $\begin{array}{c}\text { More than } \\
\text { (Mean }+1 / 2 \text { SD) }\end{array}$ & $>77.441$ & 10 & 33.33 \\
\hline & Total & & $\mathbf{3 0}$ & $\mathbf{1 0 0 . 0 0}$ \\
\hline
\end{tabular}

Mean $=75.44, \mathrm{SD}=4.014$

Thus, the minimum and maximum score one could get is 22 and 110, respectively. Higher the attitude score indicates the high favourable of respondents towards FPOs and lesser the attitude score indicates less favourable towards FPOs. The total attitude score for each respondent was obtained by adding the weights of individual responses made to the total scale items (Table 1)

The attitude scale developed was administered to 30 FPO members. Based on the mean and standard deviation, the FPO members were classified into three attitude categories namely, less favourable, favourable and more favourable.

The result from table 2 shows that 40.00 per cent of the members had favourable attitude towards the framer Producer Organization, whereas 33.33 and 26.67 per cent of the members possessed more favourable and less favourable attitude towards Farmer Producer Organization (FPO).. it can be inferred that a majority of the members (73.33\%) had favourable to more favourable attitude towards Farmer producer Organization(FPO).FPOs helps to enhance the 
producer share in the consumer rupee thereby enhancing the confidence among the peasants to continue in agriculture profession, hence a vast majority of the members $(73.33 \%)$ had favourable to more favourable attitude towards FPO. Similar trend of findings was observed by Jayantha Roy (2011), Gopala (2015) and Lakshmana reddy (2020).

In conclusion the attitude scale is found to be reliable and valid; hence it can be used to analyse the attitude of members towards FPO. On administering the attitude scale to 30 members it was found that more members $(40.00 \%)$ had favourable attitude towards FPO. The possible reason is that large number of members of FPO is small and marginal farmers in the project area. They felt the necessity of associations are more essential for their sustained development than large farmers, hence the results. FPOs helps to enhance the producer share in the consumer rupee thereby enhancing the confidence among the peasants to continue in agriculture profession. The producer share in the consumer rupee has enhanced greatly and the net income of the farmers has raised to a considerable level.

\section{References}

Edwards, A.L., 1969, Techniques of attitude scale construction. Vakils, Feffer and Simons Inc, New York. commodity-based associations, Ph.D (Agri.) Thesis (Unpub.), Univ. Agric. Sci., Bangalore, Karnataka.

Jayantha Roy, K, Narayana Gowda, K., Anand, T.N. Anand and Lakshminarayan, M.T. 2011. A scale to measure the attitude of Beneficiaries towards Mahatma Gandhi National Rural Employment Guarantee Programme. Mysore J. Agric. Sci.. 46(4): 868-873.

Lakshmana Reddy, B.S., M.S. Nataraju AND Lakshminarayan, M.T., 2020, A scale to measure the attitude of framers towards Livelihood Diversification. Int. J. Curr. Microbiol. App. Sci. 9(5): 2215-2222.

Likert, R., 1932, A technique for the measurement of attitudes. Archives of Psych., 22 (140):55.

Shanabhoga M.B, Krishnamurthy, B and Vinaykumar R., 2019, Development of a vulnerability index to assess vulnerability status of the farmers and district due to climate change. Int. J. Advanced Biological Research, 9(3):242-247.

Thurstone, L.L., and Chave, E.J., 1929, The measurement of attitude. Chicago University Press, USA. Pp. 39-40.

Thurstone, L.L., 1946, Theories of intelligence. The scientific monthly, 62(2):101-112.

Gopala, Y. M., 2015, Impact analysis of

\section{How to cite this article:}

Shivani Dechamma, B. Krishnamurthy, M. T. Lakshminarayan and Shivamurthy, M. 2020. Development of the Scale to Measure the Attitude of Farmers towards Farmer Producer Organizations (FPOs). Int.J.Curr.Microbiol.App.Sci. 9(11): 3705-3711. doi: https://doi.org/10.20546/ijcmas.2020.911.444 